\title{
Tricalcium phosphate sheets with chitosan obtained via aqueous tape casting
}

\section{(Fitas de fosfato tricálcico com quitosana obtidas via tape casting aquoso)}

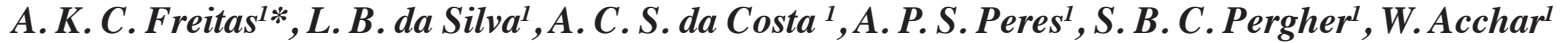 \\ ${ }^{I}$ Federal University of Rio Grande do Norte, Graduate Program in Materials Science and Engineering, \\ 59078-970, Natal, RN, Brazil
}

\begin{abstract}
Tricalcium phosphate (TCP) is a biomaterial produced in several biomedical applications, in addition to having biocompatibility and osteoconductive capacity. Biodegradable polymers of natural or synthetic origin such as chitosan and polyvinyl alcohol (PVA) have been used for tissue engineering applications because they have the properties of the native organic phase of bone tissue. Thus, the objective of this study was to obtain ceramic tapes based on TCP, chitosan, and PVA through the tape casting method. The viscosity data for all suspensions were ideal for the chosen processing. The thermogravimetric curves showed similar profiles, and it was possible to observe that a greater total mass loss occurred with the increase in the chitosan content. XRD reflections related to the $\beta$-TCP phase of the orthorhombic structure were found, showing no phase transformation. SEM analysis showed degrees of roughness on the film surfaces with little influence from the increase in chitosan content.
\end{abstract}

Keywords: tricalcium phosphate, TCP, chitosan, polyvinyl alcohol, PVA, tape casting.

\section{Resumo}

O fosfato tricálcico (TCP) é um biomaterial que está sendo produzido em diversas aplicações biomédicas, além de sua biocompatibilidade e capacidade osteocondutora. Polímeros biodegradáveis de origem natural ou sintética, como quitosana e poli(álcool vinílico) (PVA), vêm sendo utilizados para aplicações de engenharia de tecidos por apresentarem as propriedades da fase orgânica nativa do tecido ósseo. Desse modo, o objetivo deste trabalho foi a obtenção de filmes finos cerâmicos baseados em TCP, quitosana e PVA através do método de tape casting. Dados de viscosidade para todas as suspensões mostraram-se ideais para o processamento escolhido. As curvas termogravimétricas demonstraram perfis semelhantes e foi possível observar que com o aumento do teor de quitosana ocorreu maior perda de massa total. Reflexões de DRX relacionadas à fase $\beta$-TCP de estrutura ortorrômbica foram encontradas, evidenciando que não houve transformação de fases. A análise de MEV revelou graus de rugosidade nas superfícies dos filmes com pouca influência do aumento do conteúdo de quitosana.

Palavras-chave: fosfato tricálcico, TCP, quitosana, poli(álcool vinílico), PVA, tape casting.

\section{INTRODUCTION}

Chitosan is a linear biopolymer abundantly present in positively charged crustacean shells when ionized. It is considered a suitable polyelectrolyte to be used as a biomaterial due to its various properties such as adherence to mucosal surfaces, film formation, antifungal, hemostatic, bacteriostatic, analgesic, biocompatibility, renewability, low toxicity, and biodegradability [1-3]. As a result, chitosan is widely used in various applications, including artificial skin, tissue regeneration, drug delivery vehicles, stabilizing agent for metallic and non-metallic nanoparticles, gel cell immobilization devices, tissue engineering scaffolds, among others [4-8]. Another very promising material that has been studied is tricalcium phosphate (TCP) because it has excellent biocompatibility properties, in addition to being reabsorbable by the body, acting as a support for bone growth. However, there are some disadvantages to its use, such as it degrades a little faster than bone regeneration, and its mechanical strength is relatively low due to its porous structure. Therefore, studies have been performed to solve these problems to obtain TCP-based composites with different polymers in order to improve their mechanical properties [9-11]. As poly(vinyl alcohol) (PVA) has a high degree of swelling in water or biological fluids, as well as an elastic or rubbery behavior, it is able to simulate natural tissues, thus being properly accepted by the body. Moreover, it is easy to process and has advantages such as biocompatibility, non-carcinogenicity, bioadhesiveness, non-toxicity, excellent film formation capability, high mechanical strength, and transparency, thereby making it a good candidate for biomaterial [12-15]. However, it is necessary to add another component to PVA in order to increase hydrophilicity, antimicrobial activity, mechanical resistance, and to accelerate wound healing; thus, chitosan is frequently employed as it has good miscibility with PVA in aqueous medium [16].

Nowadays, innovative techniques have been used in developing films prepared by combining inorganic solid 
with organic compounds [17]. Among the various film production strategies for nanocomposite materials, there are spin-coating, dip-coating, drop-casting, tape casting, among others. In the tape casting process, it is possible to produce ceramic tapes from a suspension that contains ceramic components, solvents, and organic additives, such as dispersant, binder, and plasticizer. These additives ensure that the ceramic tape is flexible and cohesive after drying [18]. The main advantages of this technique in relation to the other mentioned methods is the simplicity combined with the efficiency of the process in order to produce a final product with better surface quality and thin pieces [19]. The use of the tape casting method for developing biomaterials enables porosity, pore size, and shape control [20]. In the present study, thin ceramic films based on TCP, chitosan, and PVA were prepared by the tape casting method, and the final properties of these films, such as green flexibility, thermal behavior, and microstructure, were investigated. This study aims to explore the benefits of producing thin films based on TCP and PVA, with and without chitosan, in order to use them in the future as a potential bone regeneration with antibacterial effect.

\section{MATERIAL AND METHODS}

Obtaining ceramic tapes: the suspension preparation consisted of a mixture of TCP (Sigma-Aldrich), distilled water, ethyl alcohol (Atriom, 99.5\%), and Triton X-114 (Sigma-Aldrich); this first mixing step was kept under stirring in an alumina container with $\mathrm{Al}_{2} \mathrm{O}_{3}$ balls (Cienlab, $60 \mathrm{rpm}$ ) for a period of $48 \mathrm{~h}$. The PVA (Sigma-Aldrich, $+99 \%$, hydrolyzed) was prepared prior to add the organic components to the suspension: it was dissolved in water at 50 to $70{ }^{\circ} \mathrm{C}$ under constant stirring. Then, after $48 \mathrm{~h}$ of stirring, PVA, isopropyl alcohol (Vetec, RG), ethyl alcohol (Atriom, 99.5\%), cocoamide (Stepan), defoamer (Miracema-Nuodex), and chitosan (Sigma-Aldrich, if present in the composition) were added to the suspension and then returned to the mill for stirring for a further $24 \mathrm{~h}$. The compositions used for preparing the suspensions can be seen in Table I. Sample nomenclature TCP-PVA-2Q\%, TCP-PVA-5Q\%, TCP-PVA$8 \mathrm{Q} \%$ are for films containing $2 \%, 5 \%$, and $8 \%$ of chitosan, respectively. A tabletop tape casting machine (TTC-1200, Tape Casting Warehouse) was used at a constant speed of $202.2 \mathrm{~mm} / \mathrm{min}$ for forming the ceramic tapes. The process was performed by a relative movement between a leveling blade, doctor blade, and a collecting surface. The doctor blade was calibrated and adjusted to a thickness of 0.725 $\mathrm{mm}$. Immediately after adjustment, the ceramic film was bonded and then dried at room temperature.

Compositional, morphological, and structural characterization. Rheological characterization: the viscosity measurement was performed in a viscometer (Haake Viscotester, Thermo Fischer Sci.) with a cone-plate system and PP20 sensor using a shear rate interval of 0 to $700 \mathrm{~s}^{-1}$. Thermogravimetric analysis (TGA): the samples were analyzed in a TGA equipment (DTG-60, Shimadzu) under an argon atmosphere at a flow rate of $50 \mathrm{~mL} / \mathrm{min}$ from room temperature to $800{ }^{\circ} \mathrm{C}$, with a heating rate of $5{ }^{\circ} \mathrm{C} / \mathrm{min}$. X-ray diffraction (XRD): X-ray diffractograms were obtained with a diffractometer (XDR-7000, Shimadzu) using $\mathrm{CuK} \alpha$ radiation $\left(\lambda=1.54 \AA\right.$ ), $2 \theta$ in the range of $10^{\circ}$ to $65^{\circ}, 0.02^{\circ}$ step, $30 \mathrm{~mA}$ current, $40 \mathrm{kV}$ voltage, and a scan rate of $1 \% \mathrm{~min}$. The crystalline phases were identified via the Joint Committee on Powder Diffraction Standards (JCPDS) database, with the aid of X'Pert HighScore software. Field emission gun scanning electron microscopy (FEGSEM): the morphology of the samples was visualized in a microscope (Auriga FEGSEM, Zeiss) with an acceleration voltage of 5 $\mathrm{kV}$, using a working distance of $3.4 \mathrm{~mm}$.

\section{RESULTS AND DISCUSSION}

Stability of ceramic suspensions: Fig. 1 shows viscosity as a function of shear rate. Suspension viscosity decreased with increasing shear rate, exhibiting a characteristic

Table I - Compositions (wt\%) of ceramic suspensions.

[Tabela I - Composições (\% em massa) das suspensões cerâmicas.]

\begin{tabular}{cccccc}
\hline Material & TCP-PVA & TCP-PVA-2Q\% & TCP-PVA-5Q\% & TCP-PVA-8Q\% & Function \\
\hline TCP & 30.0 & 30.0 & 30.0 & 30.0 & Ceramic powder \\
Distilled water & 17.0 & 17.0 & 15.0 & 15.0 & Solvent \\
Ethyl alcohol & 15.0 & 13.0 & 13.0 & 13.0 & Solvent \\
Triton X-114 & 1.5 & 1.5 & 1.5 & 1.5 & Dispersant \\
PVA & 28.0 & 28.0 & 27.0 & 24.0 & Binder \\
Chitosan & - & 2.0 & 5.0 & 8.0 & Binder \\
Isopropyl & 1.5 & 1.5 & 1.5 & 1.5 & Plasticizer \\
alcohol & & 5.0 & 5.0 & 5.0 & Solvent \\
Ethyl alcohol & 5.0 & 0.5 & 0.5 & 0.5 & Surfactant \\
Cocoamide & 0.5 & 1.5 & 1.5 & 1.5 & Defoamer \\
Liofoam 148 & 1.5 & & &
\end{tabular}


pseudoplastic behavior in the range of 25 to $700 \mathrm{~s}^{-1}$. This behavior was suitable for tape casting processing because the low viscosity at high shear rate ensured a homogeneous mass flow in the suspension, and the high viscosity at low shear rate maintained the suspension with the form of a film. At the beginning of film-forming, the shear stress arose from the internal strength from the elongation of the polymer chains and distribution of particle agglomerates, resulting in an increase in the viscosity of the entire suspension. Similar profiles were found in [21, 22]. Qiao et al. [23] noticed that the suspensions produced by tape casting exhibited pseudoplastic behavior, enabling to obtain films with flat and homogeneous surfaces, a fact that contributed to the final quality of the ceramic film.

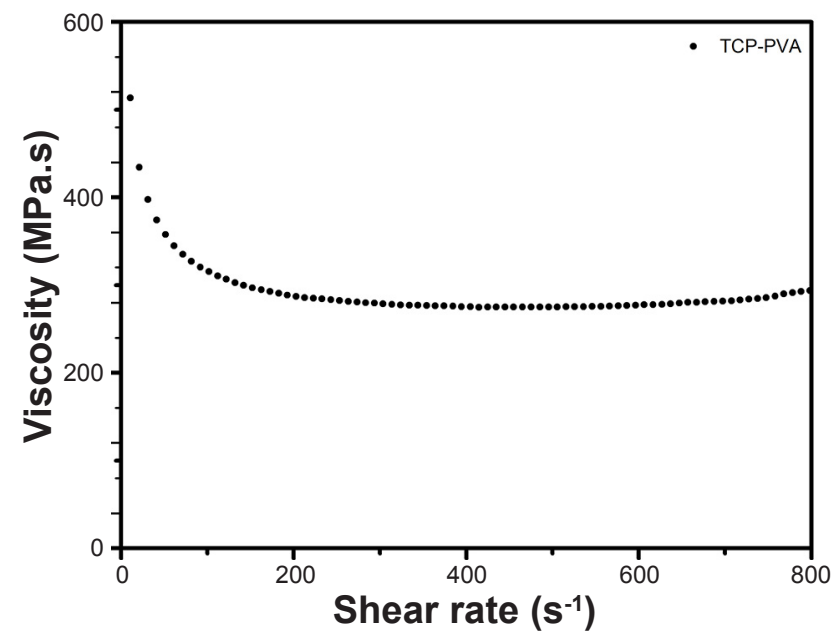

Figure 1: Viscosity curve as a function of shear rate of ceramic suspension based on TCP-PVA.

[Figura 1: Curva de viscosidade em função da taxa de cisalhamento da suspensão cerâmica à base de TCP-PVA.]

Thermal behavior: thermogravimetric analysis (TGA) was conducted to study the effect of the addition of chitosan on the thermal stability of the TCP-PVA-based ceramic tapes (TCP-PVA-2Q\%, TCP-PVA-5Q\%, and TCP-PVA-8Q\%). As shown in Fig. 2, all the samples exhibited weight loss at approximately $100-200^{\circ} \mathrm{C}$ due to the water vaporization and the degradation of the organic constituents present in the ceramic tape from the tape casting process. The second mass loss for the TCP-PVA film reference sample was at 200$400{ }^{\circ} \mathrm{C}$, with a weight loss of approximately $17 \%$. For the sample TCP-PVA-2Q\%, TCP-PVA-5Q\%, and TCP-PVA$8 \% \mathrm{Q}$, the weight losses were around $22.5 \%$ at the range of 200 to $550{ }^{\circ} \mathrm{C}, 31 \%$ at the range of 200 to $750{ }^{\circ} \mathrm{C}$, and $30 \%$ at the range of 300 to $750{ }^{\circ} \mathrm{C}$, respectively, associated with the removal of hydroxyl groups present in the composition and the decomposition of the polymer backbones [24]. The final mass loss increased with increasing chitosan content due to the higher organic content [25]. The weight loss due to the moisture in TCP-PVA film containing chitosan was higher (about 22.5-31 wt\%) compared to the pure TCP-PVA film (about $17 \mathrm{wt} \%$ ). This result showed a slight increase in degradation with increasing content of chitosan (Fig. 2), which may be related to decreasing crystallinity from the XRD analysis. The TGA curves indicated that TCP-PVA films doped with chitosan had fairly good thermal stability and the same two main steps of weight loss.

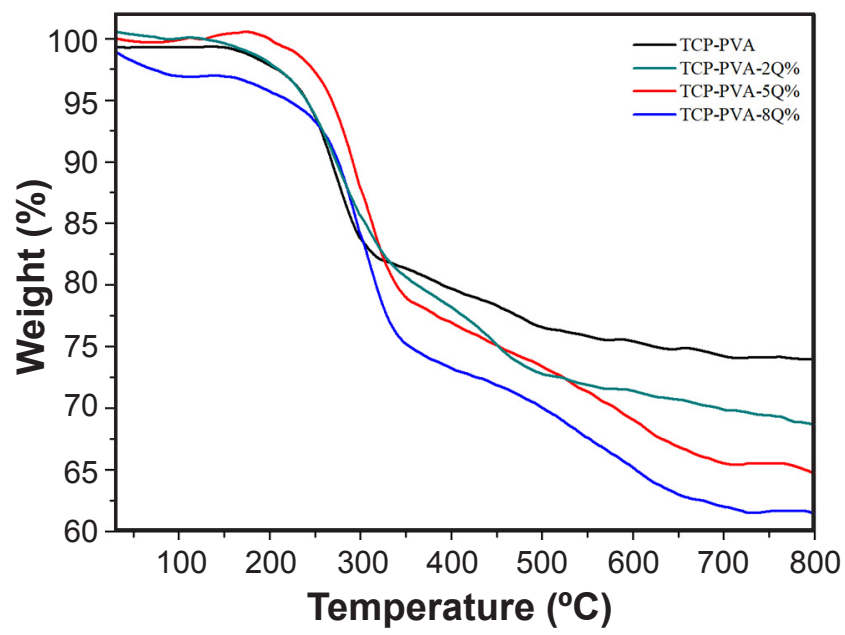

Figure 2: Thermogravimetric curves of TCP-PVA, TCP-PVA2Q\%, TCP-PVA-5Q\%, and TCP-PVA-8Q\% tapes.

[Figura 2: Curvas termogravimétricas das fitas de TCP-PVA, TCP-2Q\%, TCP-5Q\% e TCP-8Q\%.]

$X$-ray diffraction: the XRD patterns of the TCP-PVA tapes are shown in Fig. 3. The reflections in the $\mathrm{X}$-ray powder diffractograms of the ceramic tapes were attributed to the $\beta$-TCP phase (JCPDS 98-008-2984) of orthorhombic structure, with the chemical formula $\mathrm{Ca}_{3}\left(\mathrm{PO}_{4}\right)_{2}$. From the diffractograms, it was observed that there was no phase transformation due to tape casting processing, but the decrease of the intensity of the diffraction peak indicated that

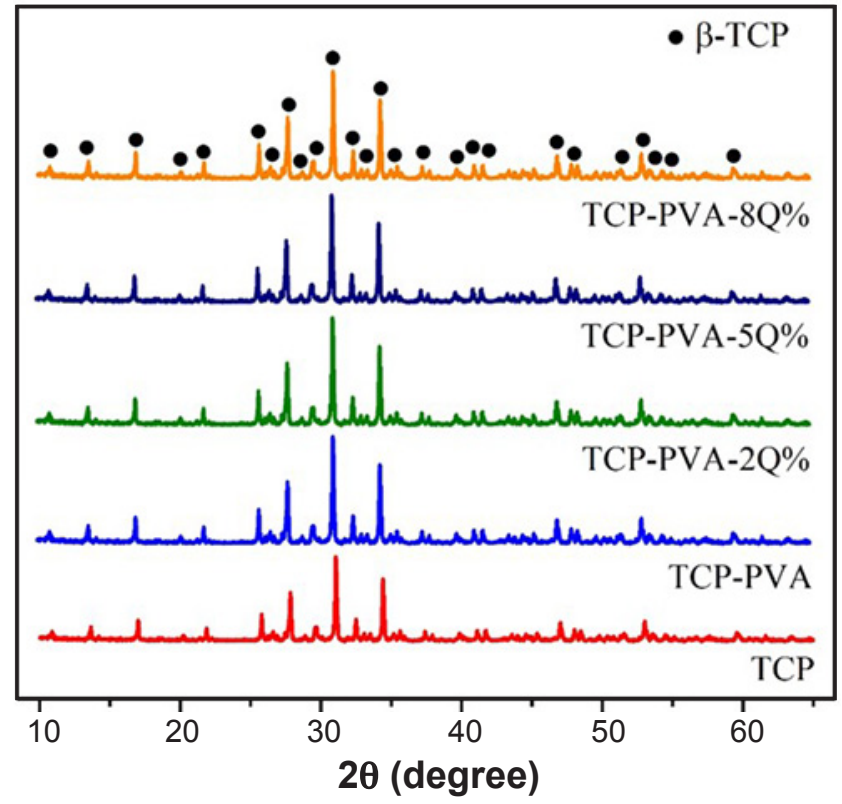

Figure 3: XRD patterns for TCP powder sample and TCP-PVA ceramic films.

[Figura 3: Difratogramas de raios $X$ para o pó de TCP e para os filmes cerâmicos TCP-PVA.] 


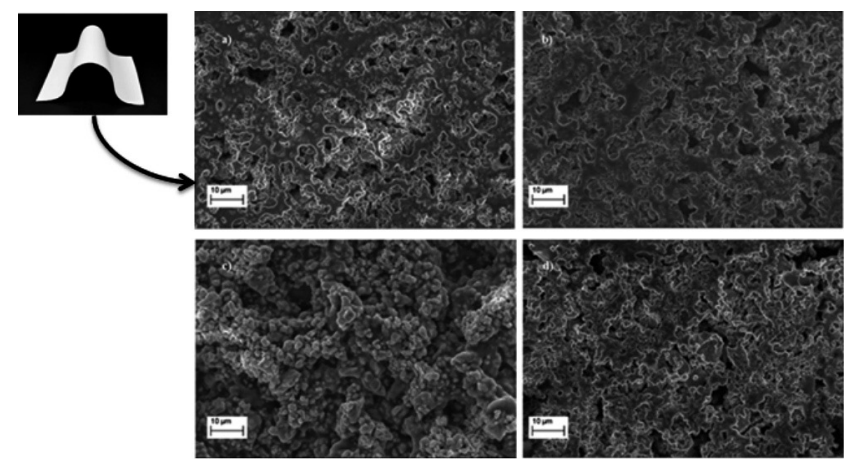

Figure 4: SEM micrographs of films of: a) TCP-PVA; b) TCPPVA-2Q\%; c) TCP-PVA-5Q\%; and d) TCP-PVA-8Q\%.

[Figura 4: Micrografias de MEV dos filmes de: a) TCP-PVA; b) TCP-2Q\%; c) TCP-5Q\%; e d) TCP-8Q\%.]

the addition of chitosan could effectively decrease the degree of crystallinity of TCP-PVA films. Mina et al. [26] suggested an inverse relationship between chitosan percentage and the peak intensity. The increase of chitosan concentration produced changes in peak intensity due to the compression stress within the $\beta$-TCP structure. No additional crystalline phases were identified. Spaniol et al. [11] also found similar results for TCP-PVA-based tapes.

Scanning electron microscopy: Fig. 4 shows the characteristic morphological aspects of thin films. When adding the binder, the amount of loose particles was lowered. The binder in the suspension was effective in increasing the cohesiveness and the compaction of particles, and providing green strength to the tape, as shown in Fig. 4a [27]. All the films demonstrated a porous morphological structure [28]; in addition, various degrees of surface roughness of $\beta$-TCP/ chitosan films were visible with different chitosan contents. From the SEM analysis, it was observed the presence of the irregular particles and film surface roughness of the $\beta-\mathrm{TCP} /$ chitosan; with the increase of chitosan up to $8 \%$, it was possible to observe an increase of irregular particles [26-28]. This was probably attributed to the polymerization of chitosan that difficulted its complete dissolution in the solution. According to [29], the porous structure is important for osteoconduction, since it resembles the human bone structure.

\section{CONCLUSIONS}

Thin films based on tricalcium phosphate (TCP), chitosan, and polyvinyl alcohol (PVA) were developed through the tape casting method, proving to be effective in obtaining homogeneous and flexible films. The addition of chitosan in the TCP matrix formed a homogeneous porous microstructure, and, with the increase of its content, a larger mass loss was observed in the thermogravimetric analysis. The obtained results provided an important insight for the films to be applied in bone regeneration, as it is a simple, easy and inexpensive method, using biodegradable and biocompatible materials, and the appropriate produced material is an alternative to the bone graft. However, the need for further biocompatibility and cytotoxicity testing, among others, is indispensable. Achieving these results will involve close collaboration between materials scientists, synthetic chemists, cellular and molecular biologists, physicists, and orthopedic surgeons.

\section{ACKNOWLEDGMENTS}

The authors thank the National Council for Scientific and Technological Development (CNPq, Brazil) and the Higher Education Personnel Improvement Coordination (CAPES, Brazil) for their financial support for research.

\section{REFERENCES}

[1] M.H. Periayaha, A.S. Halima, A.R. Husseinb, A.Z.M. Saada, A.H.A. Rashide, K. Noorsald, Int. J. Biol. Macromol. 52 (2013) 244.

[2] C.Y. Yoo, J.S., Seong, S.N. Park, Colloids Surf. B 144 (2016) 99.

[3] A.S. Halim, F.M. Nor, A.Z.M. Saad, N.A.M. Nasir, B. Norsa'adah, Z. Ujang, J. Taibah Univ. Med. Sci. 13 (2018) 512.

[4] M.C.M. Laranjeira, V.T. Fávere, Quím. Nova 32, 3 (2009) 672.

[5] Y. Luo, Z. Teng, Y. Li, Q. Wang, Carbohydr. Polym. 122 (2015) 221.

[6] A. Leiva, S. Bonardd, M.Pino, C. Saldías, G. Kortaberria, D. Radic, Eur. Polym. J. 68 (2015) 419.

[7] M. Collado-González, M.G. Montalbán, J. Peña-García, H. Pérez-Sánchez, G. Víllora, F.G.D. Baños, Carbohydr. Polym. 161 (2016) 63.

[8] X. Jing, H.-Y. Mi, B.N. Napiwocki, X.-F. Peng, L.-S. Turng, Carbon 125 (2017) 557.

[9] K. Leja, G. Pol, J. Environ. Stud. 19 (2010) 255.

[10] S.V. Dorozhkin, Biomaterials 31 (2010) 1465.

[11] K.G. Spaniol, S.C. Caldas, A.P.S. Peres, E.A. Santos, W. Acchar, Ceram. Int. 45, 9 (2019) 12417.

[12] S. Baghaie, M.T. Khorasani, A. Zarrabi, J. Moshtaghian, J. Biomater. Sci. Polym. Ed. 28, 18 (2017) 2220.

[13] G.R. Mahdavinia, M. Soleymani, H. Etemadi, M. Sabzi, Z. Atlasi, Int. J. Biol. Macromol. 107 (2018) 719.

[14] N. Golafshan, R. Rezahasani, M. Tarkesh, Esfahani, M. Kharaziha, S.N. Khorasani, Carbohydr. Polym. 176 (2017) 392.

[15] L.F. Santos, I.J. Correia, A.S. Silva, J.F. Mano, Eur. J. Pharm. Sci. 118 (2018) 49.

[16] M.J. Afshari, N. Sheikh, H. Afarideh, Radiat. Phys. Chem. 113 (2015) 28.

[17] E. Ruiz-Hitzky, M. Darder, F.M. Fernandes, B. Wicklein, A.C.S. Alcântara, P. Aranda, Prog. Polym. Sci. 38 (2013) 1392.

[18] F.D. Minatto, P. Milak, A. De Noni, D. Hotza, O.R.K. Montedo, Adv. Appl. Ceram. 114 (2014) 127.

[19] D. Hotza, Cerâmica 43, 283-284 (1997) 157.

[20] Y. Tanimoto, M. Teshima, N. Nishiyama, M. Yamaguchi, S. Hirayama, Y. Shibata, T. Miyazaki, J. Biomed. Mater. 
Res. B Appl. Biomater. 100 (2012) 2261.

[21] A.P.S. Peres, A.C.S. Costa, F. Bohn, M.A. Correa, W. Acchar, C.A. Paskocimas, Ceram. Int. 44 (2018) 16062.

[22] J. Luo, R. Eitel, Ceram. Int. 44 (2018) 3488.

[23] Y. Qiao, Y. Liu, A. Liu, Y. Wang, Ceram. Int. 38 (2012) 2319.

[24] Q. Ma, L. Du, Y. Yang, L. Wang, Food Hydrocoll. 63 (2017) 677.

[25] M.T. Laranjo, F.M. Morawski, S.L. Dias, E.V. Benvenutti, L.T. Arenas, T.M. Costa, J. Braz. Chem. Soc.
30 (2019) 2660.

[26] A. Mina, H.H. Caicedo, J.A. Uquillas, W. Aperador, O. Gutierrez, J.C. Caicedo, Mater. Chem. Phys. 175 (2016) 68. [27] C.O. Renó, R.G. Carrodeguas, M. Motisuke, M.A. Rodríguez, Cerâmica 65, 376 (2019) 599.

[28] A. Ali, S. Bano, R. Priyadarshi, Y.S. Negi, Mater. Today Proc. 15 (2019) 173.

[29] M. Khodaei, A. Valanezhad, I. Watanabe, J. Environ. Friendly Mater. 2.2 (2018) 1.

(Rec. 13/01/2020, Rev. 16/03/2020, 19/05/2020, Ac. 21/05/2020) 